African Journal of Educational Studies in Mathematics and Sciences Vol. 15, 2019

Contents Volume 15, 2019 



\title{
Philosophy of teaching, teaching style and ICT use: a qualitative study of the perspectives of high school mathematics teachers
}

\author{
F. S. ${ }^{1}$ Mensah \& D. D. ${ }^{2}$ Agyei
}

\begin{abstract}
This study is a response to findings that have shown the importance of teachers' philosophy, teaching styles and ICT use in impacting student learning outcomes. The study adopted an exploratory case design to explore the philosophical foundations, teaching styles and the levels of ICT use of six high school mathematics teachers in Ghana. Data for the study was collected using semi-structured interviews. The study found that the high school teachers used mainly the teacher-centered teaching approaches in which they dominate classroom instruction by disseminating knowledge to their learners. In spite of its perceived potentials, the study also reported low usages of ICT in instructional delivery among the teachers. Interestingly, the philosophy of teaching reported in the study by the teachers resonates with their current teaching style and ICT usage levels; the study found that the high school mathematics teachers hugely subscribed to the absolutist philosophical views of teaching mathematics which takes root in teacher-dominated teaching approaches. Consequently, the study reiterates that if teachers hold philosophical views that support the absolutist school of thought, they are likely to use delivery strategies which do not support ICT use but position the teacher to assume a central role in the instructional processes.
\end{abstract}

Keywords: $\quad$ philosophy of teaching; teaching style; ICT usage, instructional processes

\section{Introduction}

The study is in response to findings from research studies (Wims \& Lawler, 2007, Stein, Smith, Henningsen, \& Silver, 2016; Mensah, 2017) that have shown the importance of teachers' philosophy, teaching styles and ICT use among others in imparting student learning outcomes. In Ghana, current reforms in mathematics teaching and learning at the high school level is rooted in an evolving vision of school mathematics, one that incorporates constructivist learning, studentcentered pedagogy, ICT usage and the use of worthwhile tasks (National Council of Teachers of Mathematics, 2000). Yet many a time, mathematics teachers are so concerned with "getting to the end of the book" that they forget about teaching for understanding.

Albeit the existence of several literature (Ernest 2004; Wentzel, 2002) on mathematics teachers' philosophies, teaching styles and ICT usage, it is difficult to find any holistic study that explores the relationships among these key issues and the roles they play in the mathematics instructional

\footnotetext{
${ }^{1}$ Farouq Sessah Mensah, Mathematics Tutor, Ekumfi T.I. Ahamdiyya Senior High School, Cape Coast. Email: farouq.mensah@stu.ucc.edu.gh

${ }^{2}$ Douglas D. Agyei, Associate Professor, Mathematics Education, University of Cape Coast, Department of Mathematics and ICT Education. Email: ddagyei@ucc.edu.gh
} 
Philosophy of teaching, teaching style and ICT use: a qualitative study of the perspectives of high school mathematics teachers

F. S. Mensah \& D. D. Agyei

processes. Most studies (Hart, 2002; Mewborn, 2002) conducted in the western world seem to question the kind of philosophies teachers should hold about mathematical instructional delivery. Others have explored the effectiveness of different teaching styles (Wentzel, 2002; Grasha, 2002) and the potential of ICT usage (Higgins \& Moseley, 2001, Tall \& Ramos, 2004) in teaching mathematics. Thus, the literature suggests that there is paucity of information on the connectedness of mathematics teachers' philosophies, their preferred teaching styles and their ICT usage. The situation however, is not different from studies conducted in the sub-Saharan regions. Some studies (Mensah, 2017; Agyei 2013) conducted in the region focused on the individual variables but not the interconnections between them. This study therefore has a focus not only to explore high school mathematics teachers' perceived philosophical foundations, teaching styles and ICT usage in instructional delivery, but also to establish if there exist any kind of connection between these phenomena or not, in the case of Ghana.

\section{Teaching Philosophy}

In this section, we have discussed two major blocks of divergent views of the philosophy of teaching mathematics. On the right extreme, one school of thought holds the view that mathematics is an exact science so its truths are absolute; this is known as the Absolutist view.

This group of scholars hold the philosophy that mathematics is an objective, absolute, certain and incorrigible body of knowledge, which rests on firm foundations of deductive logic. An absolutist teacher's view may be communicated in the school system by giving students mainly unrelated routine mathematical tasks which involve the application of learnt procedures, and by stressing that every task has a unique, fixed and objectively right answer, coupled with disapproval of any failure to achieve the expected answer. This may not be what the mathematician perceives as mathematics, but a result is nevertheless an absolutist conception of the subject (Buerk 1982).

A more recent position in the philosophy of mathematics is Fallibilism, which emphasizes the practice of mathematics and the human side of mathematics to counter absolutism (Lakatoes, 2015). Fallibilism is a constructivist philosophy with their tenet that people construct knowledge in their minds including mathematical knowledge. Thus, all mathematical knowledge is the product of human creation, the product of their intelligence and hence cannot exist independent of them as the Absolutist argue.

\section{Teaching Styles}

Several teaching styles have been acknowledged in the literature (Grasha \& Yangarber-Hicks, 2000; Grasha, 2002). One teaching style is the teacher-centred approach where teacher dominates the classroom instruction by disseminating knowledge to the learners (Khalid \& Azeem, 2012). According to research studies (Khalid \& Azeem, 2012) the teacher- centred teaching approach hinders learners' creativity and contribution of ideas, encourages rote learning, and discourages learning from understanding. Another reported teaching style is the personal or learner-centred (Grasha \& Yangarber-Hicks, 2000; Grasha, 2002), in which the teacher is seen merely as a facilitator of knowledge and instruction. The style allows learners to work independently either individually or in small groups, while the teacher acts as a consultant and resource manager (Grasha \& Yangarber-Hicks, 2000; Grasha, 2002). 


\section{ICT Use in Mathematics Instructional Delivery}

Until recently, the instructional strategy adapted in most mathematics classrooms was the teachercentered (chalk and talk) approach (Agyei, 2013), in which teachers does most of the talking and intellectual work, while students are passive receptacles of the information provided. The high school mathematics teaching syllabus places emphasis on the use of ICT in teaching and learning (Ministry of Education, Science and Sports, 2010). Several studies have revealed the important role ICT plays in teaching and learning mathematics. For instance, Becta (2003) assert that the use of technology in mathematics classroom allows the students to focus on strategies and interpretation of answers rather than spend time on tedious computational calculations.

\section{Methodology}

\section{Research Design and Participant}

The study employed an exploratory case study design to explore the philosophical foundations, teaching styles and ICT usage levels of six high school mathematics teachers' instructional processes. An exploratory case study is a type of qualitative research that aims at exploring any phenomenon in the data which serves as a point of interest to the researcher (Zainal, 2007). The cases of this study comprised of six senior high mathematics teachers from six different high schools in the Central region of Ghana. Using an exploratory case study, the mathematics teachers' endeavours and explanations were contextualized within the school environment to investigate the reality of their perceived philosophies in teaching mathematics, teaching style and ICT usage. We examined the six individual cases and compared them to develop a general understanding of the phenomena in which we were interested (Putney, 2010).

Findings from the interviews indicated that all the participant collectively had a wealth of teaching experience not less than seven years. At the time of the study, the participants reported that they were teaching either core mathematics or elective mathematics, however, Gifty and Dickson reported they teach both core and elective mathematics; they all indicated that they were professional mathematics teachers. Based on their responses, Panford and Mavis taught high school 1 classes only, Gifty and Dickson taught high school 1 and 2 classes, Seidu taught high school 2 classes only, Kate taught high school 2 and 3 classes' whiles Isaac taught high school 3 classes only. This is an indication that the participants cut across all the classes in high school. The responses also showed that all the participants in the study held at least a position in the school they served. Seidu, Kate and Mavis were House Staff, Dickson a Form Master and Isaac a Head of Department (Mathematics). Gifty was the Coordinator for the National Science and Maths Quiz Team and an Examination Officer for her school whiles Panford was the Soccer Coach, Patron for the Journalism Club and Master of Ceremony (MC) for his school on occasions. Further details of the high school mathematics teachers' background that were reported are summarised in Table 1. 
Philosophy of teaching, teaching style and ICT use: a qualitative study of the perspectives of high school mathematics teachers

F. S. Mensah \& D. D. Agyei

Table 1: $\quad$ Summary of High School Mathematics Teachers' Background

\begin{tabular}{|c|c|c|c|c|c|c|}
\hline Name & Gender & $\begin{array}{l}\text { Qualification } \\
\text { (Academic/ } \\
\text { Professional) }\end{array}$ & $\begin{array}{l}\text { Teaching } \\
\text { Experience } \\
\text { (In Years) }\end{array}$ & $\begin{array}{l}\text { Subject } \\
\text { Area } \\
\text { Currently } \\
\text { Teaching }\end{array}$ & $\begin{array}{l}\text { Class } \\
\text { Taught }\end{array}$ & $\begin{array}{l}\text { Position } \\
\text { Held in } \\
\text { School }\end{array}$ \\
\hline Isaac & Male & $\begin{array}{l}\text { B.Sc. } \\
\text { Mathematics, } \\
\text { PDGE }\end{array}$ & 16 & $\begin{array}{l}\text { Elective } \\
\text { Mathematics }\end{array}$ & $\begin{array}{l}\text { High } \\
\text { School } 3\end{array}$ & $\begin{array}{l}\text { HOD, } \\
\text { Mathematic } \\
\text { s }\end{array}$ \\
\hline Gifty & Female & $\begin{array}{l}\text { B.Sc. } \\
\text { Mathematics, } \\
\text { PDGE }\end{array}$ & 22 & $\begin{array}{l}\text { Elective } \\
\text { Mathematics, } \\
\text { Core } \\
\text { Mathematics }\end{array}$ & $\begin{array}{l}\text { High } \\
\text { School } 2 \\
\& 1\end{array}$ & $\begin{array}{l}\text { Coordinator, } \\
\text { National } \\
\text { Science and } \\
\text { Maths Quiz } \\
\text { Team, } \\
\text { Examination } \\
\text { Officer }\end{array}$ \\
\hline Seidu & Male & $\begin{array}{l}\text { B.Ed. } \\
\text { Mathematics, } \\
\text { M.Ed. } \\
\text { Mathematics }\end{array}$ & 12 & $\begin{array}{l}\text { Core } \\
\text { Mathematics }\end{array}$ & $\begin{array}{l}\text { High } \\
\text { School } 2\end{array}$ & $\begin{array}{l}\text { House } \\
\text { Master }\end{array}$ \\
\hline Dickson & Male & $\begin{array}{l}\text { B.Ed. } \\
\text { Mathematics, } \\
\text { M.Sc. Statistics }\end{array}$ & 24 & $\begin{array}{l}\text { Elective } \\
\text { Mathematics, } \\
\text { Core } \\
\text { Mathematics }\end{array}$ & $\begin{array}{l}\text { High } \\
\text { School } 2 \\
\& 1\end{array}$ & $\begin{array}{l}\text { Form } \\
\text { Master }\end{array}$ \\
\hline Panford & Male & $\begin{array}{l}\text { B.Ed. } \\
\text { Mathematics }\end{array}$ & 10 & $\begin{array}{l}\text { Core } \\
\text { Mathematics }\end{array}$ & $\begin{array}{l}\text { high } \\
\text { School } 1\end{array}$ & $\begin{array}{l}\text { Soccer } \\
\text { Coach, } \\
\text { Patron } \\
\text { Journalism } \\
\text { Club, MC } \\
\text { for } \\
\text { Occasions }\end{array}$ \\
\hline Kate & Female & $\begin{array}{l}\text { B.Ed. } \\
\text { Mathematics }\end{array}$ & 19 & $\begin{array}{l}\text { Core } \\
\text { Mathematics }\end{array}$ & $\begin{array}{l}\text { High } \\
\text { School } 2 \\
\& 3\end{array}$ & $\begin{array}{l}\text { House } \\
\text { Mistress }\end{array}$ \\
\hline
\end{tabular}

\section{Data Collection and Analyses}

The evidence for the study was collected by the use of semi - structured interview. All the six participants took part in a semi-structured interview protocol over a period not exceeding 60 minutes. The interview protocol framed, focused on the research questions, gathering data about participants' teaching philosophy, teaching styles and ICT use. The interviews were audio taped and transcribed. Data collected through interviews were analyzed qualitatively using data reduction techniques in which major themes (teachers' teaching philosophy; teaching style and 
their ICT use) were identified and clustered (Miles \& Huberman, 1994). We built a portrait of each individual teacher based on the themes and described their classroom experiences in detail, guided by the interview questions.

\section{Results}

The results of analyzing responses to the semi - structured interviews of the high school mathematics teachers are presented in this section. The results are presented in themes generated that guided the conduct of this study.

\section{Philosophy of Teaching Mathematics}

An account of the teachers' philosophy regarding teaching of mathematics at the high school level is discussed. Isaac told us that his teaching philosophy was about "imparting knowledge" to students. According to him, his goal was to make students understand what he was talking about and why they were learning mathematics. For instance, he told us that they were times that students asked him why they were learning certain mathematics concepts and where they would apply that knowledge in real life. He told us how he demonstrated the application of mathematics in his instructional delivery and assessment of students in such instances. Hence, Isaac's philosophy of teaching mathematics seems to align with that of the right-wing teacher (Absolutist view).

When we asked Gifty to talk about her teaching philosophy, she told us that her teaching philosophy was centered on students' excellence in education. She stated:

"it becomes very unfortunate when you have given your best and the results are not reflective".

The comment here seems to imply that Gifty constructed her teaching philosophy based on whether her students had succeeded in school or not. Apparently, she felt that teachers at her school spend a lot of time dealing with disciplinary issues other than supporting students' learning. This is an indication that Gifty's philosophical stand conforms to that of an Absolutist as was observed in the case of Isaac.

Seidu also had the following to say in relation to his teaching philosophy:

"Finding ways of making the student learn is what interests me. So that makes me a reflective teacher. I have to find a way of looking back to what I have done and being able to adjust them accordingly."

Seidu perceived his teaching philosophy to be grounded in "learning how they learn". He added that although it is a challenge, he finds ways of looking back and adjusting his instructional approaches accordingly to what suits his students' learning needs. According to him, reflection and adjustment of teaching practice is guided by "what others say" about the practice of teaching. As can be inferred from the comments, Seidu's teaching philosophy seems to align to that of the Absolutist.

When we asked Dickson what his teaching philosophy was, he stated:

“...the students' discussions; if the students are receptive and they are willing to communicate. But if the concept is not sinking in, sometimes I get a bit demoralized. I don't know how to simplify it".

Dickson noted that he enjoyed teaching and that the feedback he got from his students motivated him to keep going. However, his comment suggests that he gets frustrated when his students do not conceptualise the subject matter he is presenting to them. Apparently, Dickson envisages a 
Philosophy of teaching, teaching style and ICT use: a qualitative study of the perspectives of high school mathematics teachers

F. S. Mensah \& D. D. Agyei

classroom situation where his students will be able to communicate rightly back to him on routine mathematical task given to students. This obviously suggest an Absolutists' philosophical view.

Panford stated that he believed in assigning students a lot of homework questions to practice, besides making every effort to complete the syllabus as early as possible to prepare his students for the West African Senior School Certificate Examination (WASSCE). In an attempt to complete the syllabus, Panford also noted the usefulness of peer teaching as a strategy for covering lots of topics; he explained that he does this by assigning specific topics to students to master and teach their peers accordingly. Based on these comments, Panford seems to have a teaching philosophy that aligns with that of the Absolutist.

For Kate, when we asked what her teaching philosophy was, she stated that she has learned to motivate her students to overcome social and life challenges so that the students could exceed expectations and become self-reliant citizens. According to her, she had a great passion for the girl child in mathematics learning "because it will open doors" for the girl child. In Kate's view, success in mathematics may lead to great careers for these students. She described the type of students she gets from basic school:

"They are great children. They got 1's at the basic level [on the Basic Education Certificate Examination, (BECE)]; I want them to leave this school with Al's".

This seem to suggest that Kate is result-oriented. Kate also stated that she had managed to convince her students that mathematics is the "master key" in life. By this, she meant that, mathematics applies to other subjects and is useful in many professions. She added that when she is teaching mathematics, she tells stories to her students to get their attention, to develop a relationship with them, and to relate mathematics to real-life situations. This is one example of the real-life stories Kate told us:

"I give them an example of the Election petition, in which the state lawyers had to defend the Electoral Commission (EC). I explained to them that, had it not been their knowledge in statistics, the lawyers would not have been able to identify areas where the total number of ballots cast exceeded the total number of registered voters in some electoral areas or identify trends in voting which showed a number of anomalies. This is a very open case I use in my class to demonstrate the application of mathematics in real life."

Kate also noted that they (i.e. Kate and her students) have an adage which goes like "run away from maths at your own risk". According to Kate, when students look at her they think she is their future. From this perspective, Kate seem to hold a blend of the Absolutist and Social Constructivism philosophy of teaching mathematics.

High School Mathematics Teachers' Teaching Styles

According to Isaac, his teaching style involves giving students a few examples followed by some exercises for students to complete. He told us that:

"you give them a question to try because it is a build-up of a lower form".

He seems to imply that he expected students to have some basic knowledge from lower classes of certain mathematical concepts that could help them work on more challenging mathematics problems which could be aligned to be student - centered approach of teaching. 
When we asked Gifty about her teaching style, she told us that she had tried to practice studentcentered approach but that had not worked for her because her school had minimal instructional resources to facilitate satisfactory teaching practices. She stated:

"you like them to do, but if you give them a question, they start moving. This is because of the high students to book ratio. It is supposed to be one to one".

For Gifty, there were many students who did not have textbooks in her class and that inhibited her from practicing student-centered approach but teacher-centered approach to teaching.

Seidu felt that a student-centered approach to learning was the best for him. He told us that he was making efforts to practice this type of student-centered approach in his teaching because he had realized that this teaching method enabled his students to become independent learners;

"they become independent; they don't depend on anyone. They can learn on their own and therefore they are able to learn everything, apart from the subject I teach. This is something I have picked from my class".

When Dickson was asked about his teaching style, he stated that he likes to balance between teacher-directed and student-centered instructional approaches. He noted:

"I feel that if it is not teacher directed, I will not be able to know if the child is getting what I am saying. With the student-centered, you know, the child is left with the problem".

His perception was that the student-centered approach leaves many unanswered questions for the learner, and if some concepts are not corrected and clarified, that will not be helpful to the learner in the long run. The discussion revealed that Dickson seems to be an enthusiastic teacher who was committed to his students' learning.

Panford stated that his personal teaching goals include: (1) completing the syllabus as early as possible, (2) giving students a lot of work to practice, (3) peer teaching among students, and (4) teacher collaboration to support weak students and learn from expert teachers. Panford also believes in the lecture method teaching style where he leads the lesson, then partitions the lesson in instances when students can work on mathematics problems on the blackboard.

According to Kate, mathematics requires a meticulous mind that requires a good mastery of details. In the class setting, Kate told us that she had a classroom representative for some time now so that whenever she goes to class or not, mathematics learning does not stop. She told us when she delays coming to class:

"that child stands up and corrects the work, finds out where it is difficult and they do the problem on the board. They present themselves and the class goes on".

According to Kate, she intends to make mathematics learning as learner-centered as possible.

High School Mathematics Teachers' ICT Use

Isaac seemed to be enthusiastic using ICT in instructional delivery and assessment but he reported that, he did not use ICT in his instruction as he would have wanted to because not all the classroom buildings in his school had the infrastructure to support ICT usage. According to him, the school had one smart board located in a medium-sized ICT laboratory where he taught two groups of students with different learning abilities.

Gifty told us that along with mathematics teachers' lack of exploration on ICT strategies and 
Philosophy of teaching, teaching style and ICT use: a qualitative study of the perspectives of high school mathematics teachers

F. S. Mensah \& D. D. Agyei

phobia of ICT, there was a general tendency of being "very conservative". She stated:

"We want to do things the way we know how to do without ICT. We also teach our subjects because we learned them in school, so we basically teach like how our teachers taught us. And because we excelled with how the teachers taught us, I think anybody would pass if I teach them the way I was taught. My teacher never used the computer or any technology and so I have no business using technology".

Gifty was of the view that, even if mathematics teachers have access to ICT tools, rigidity to change is the main reason why teachers have not adopted ICT in their instruction. To her, the beliefs of wanting to stick to the old ways of teaching may hamper ICT use.

Seidu noted how ICT had changed his teaching approach. He stated;

"my pedagogy cannot remain the same because I have a new tool that enables facilitation of learning and therefore I have change from an instructor telling everything".

He reiterated that, he had to make conscious effort to learn how to use ICT, how to facilitate, and how to make ICT be understood by others. He had this to say;

"ICT also guides how to approach a particular concept because there are a number of options, such as photographs, simulations, videos. Sometimes using them for different session, section, unit, makes me change the way I teach, I cannot approach things the same way".

The obvious limitation he reported however, had got to do with his limited ICT knowledge/skills. According him, this has delayed his plan of implementing ICT in his instructional goals to the optimum.

Dickson described visualization of ideas as an aspect of ICT that would help his students to learn mathematics effectively. When we asked him how he thought ICT would change him as a mathematics teacher, he told us ICT would make a mathematics teacher more prepared. He noted:

"I think the teacher will now be getting more prepared in the lesson better. Because with my experience of 24 years of teaching, I do not need to prepare before going to class. But when I have the ICT with me, I have to make sure things are working, and this is how I am going to approach it. Maybe it will just make us better prepared".

Dickson seems to imply that; 24 years of teaching was a long time and that he was a very experienced mathematics teacher in terms of pedagogical and content knowledge. He also seemed to imply that without ICT he would not need to prepare a lesson, because he has taught all of the curriculum and has a repertoire of lessons. However, if ICT was now available for him to use, he would need to decide how to approach the lesson. Dickson explained how difficult it can be to teach some topics without ICT. He indicated;

"I am imagining when you are trying to draw that 3-D on the board and it is not coming out clearly. The student could perceive it as a rectangle when that is not what you intended to show. Similarly, it quite difficult to teach some concept like, the pyramid and global mathematics. Although the teacher may want to go class with some teaching models to explain such concepts, such topics become very easy for them to teach with ICT".

Thus, Dickson believes that, teaching certain abstract concepts in mathematics using ICT would make the work easier for the teacher because students will understand the mathematical concepts more clearly. 
When we asked Panford how he felt about the benefits of computer-based instruction in mathematics teaching, he stated that he had some reservations about the use of ICT in the mathematics classrooms. He believed in a "50-50 approach [half of the time]" where there was no break from the traditional way of instruction. He told us that mathematics requires a lot of explanation and contact hours during instruction. According to Panford, it is possible that in a technology-integrated lesson a student may find a concept that is abstract, and most likely the student would veer off from the lesson to start doing other things that are not related to mathematics learning. He also felt that ICT makes students omit a lot of procedural steps when they use calculators either in the examinations or for class assignments. He stated, "most of them feel if I can key in the values and get the correct answer then why should I struggle, showing how I solved it. So, it is a big problem we are facing currently"

Panford believed in the use of ICT because he had seen how it made work easy for people. He gave us an analogy of how architects do not draw with pencils anymore because they use ICT and that makes their work very easy. He noted;

"I believe that if a teacher can be able to manipulate things using technology, then why should he or she struggle to manually use the chalk, duster and the paraphernalia?"

In addition to this, he also thought that "graphing using visual [ICT] is better than blackboard because one will be able to label correctly".

Kate stated that despite many challenges that prompt teachers not to use ICT, a lack of interest in ICT also inhibits teachers from adopting it;

"I am going to be very sincere; the interest is not there. You know this better. I have not seen anybody with interest. The saying that you cannot teach an old dog a new trick applies with most teachers; we are not old but it is hard".

According to Kate, it is not only age that hinders teachers from using ICT, but also teachers do not like new things;

"I would rather stick to my book, go teach, just stick to the old methods of walking in the class having nice time, tell stories, go...".

\section{Discussion}

In this study, we sought to investigate the perceived philosophical foundations of high school mathematics teachers, teaching styles and their ICT usage.

The study reported that, four out of the six high school mathematics teachers who were interviewed hugely subscribed to the absolutist (Lerman, 1990) philosophical view of mathematics, probably because they are not exposed to other schools of thought. Once, teachers were not exposed to the various philosophical perspective in mathematics and how they could 'blend' them, it was difficult to classify the mathematics teachers as dynamic mathematics teachers who could incorporate all the philosophical stands in mathematics with the exception of Gifty. The mathematics teachers in the study perceived mathematics as an exact science just as every ordinary person does and taught high school mathematics as right-wing teachers (absolutist view). This is contrary to the task expected of the mathematics teacher; to ensure that learners discover mathematics concepts through deductive reasoning and not just learning in abstraction.

Teaching style in this study referred to teachers having learning - centered, teacher - centered, or a combination of learner and teacher-centered teaching approaches. Although several measures 
Philosophy of teaching, teaching style and ICT use: a qualitative study of the perspectives of high school mathematics teachers

F. S. Mensah \& D. D. Agyei

have been taken to improve the Ghanaian high school curriculum to purposely empower students in their learning, the findings of the study have shown that high school mathematics teachers are mainly perceived to be using teacher-centered teaching approaches. The finding of the study is consistent with that of Zilimu (2014) who found that high school mathematics teaching and learning processes are dominated by teacher-centered teaching approaches where mathematics teachers in the study dominated their classroom instruction while students were occasionally given the chance to participate or contribute their ideas on the subject matter. This is contrary to the constructivist perspective, which advocates that learners should take responsibility in their learning and that the teacher must act as the facilitator in students' learning and not only source of learning (Khalid \& Azeem, 2012).

Although ICT use in mathematics improves mathematics teaching and learning, the perceived level of ICT use in teaching mathematics in this study was low. This finding is consistent with that of Boakye and Banini (2008), who concluded that majority of the teachers in high school level in Ghana do not use ICT in classrooms but often use ICT to prepare lesson notes, browse the web and send emails. This finding is also consistent with similar studies carried out in different countries. For instance, in United Kingdom, Waite (2004) found that even though teachers showed great interest and motivation to learn about the potential of ICT, in practice, the use of ICT was relatively low and it focused on a narrow range of applications with word processing being the predominant use. This is an indication that the use of ICT in mathematics instruction is yet to be realized and utilized in the context just as reported in many other regions.

\section{Conclusion}

Four, out of the six mathematics teachers used the teacher-centered teaching style only to conduct their instruction. The teachers dominated classroom instruction, resulting in minimal students' participation in the learning. In most instances, the teachers discussed, explained, and demonstrated mathematical concepts to students, while the students had little or no chance to contribute to their own learning processes. Such teaching style seem to have an impact on the learning that takes place in the mathematics classroom but could compromise students' complete understanding of the subject matter.

Notwithstanding the importance of ICT use in high schools, the empirical evidence suggests that its use for instructional delivery is minimal in the current study. Yet the high school mathematics teachers seemed fully aware of the benefits to be derived when ICT is used in their professional career. This digital disconnect at the high school level can be attributed to endogenous and exogenous factors which are not discussed in this study. Furthermore, the study has showed new insights into the philosophical foundations of the high school mathematics teachers in relation to developing students' understanding of mathematics. We found that the high school mathematics teachers in the study subscribed to the absolutist philosophical view. This finding was not surprising, because the teachers seemed not to be exposed to the various philosophical perspective in mathematics and how they could 'blend' them to support student learning. Interestingly, the teachers' philosophical views were observed to relate to their teaching style and low ICT usage in mathematics instructional delivery. They were seen to use more of the teacher-centered teaching style which is enshrined in the absolutist philosophical school of taught; a philosophical view which does not support ICT use. Thus, the teaching style reported by the high school mathematics teachers and their ICT usage levels were just a reflection of their teaching philosophy. 


\section{References}

Agyei, D. D. (2013). Effects of using interactive spreadsheet as a demonstrative tool to enhance teaching and learning of mathematics concepts. International Journal of Educational Planning \& Administration, 3(1), 81-99.

Becta (2003). What the research say about using ICT in maths. UK: Becta ICT Research. Retrieved November 13, 2017, from http://www.becta.org.uk.

Boakye, K. B., \& Banini, D. A. (2008). Teacher technology readiness in Ghana. K. Toure, TMS Tchombe, \& T. Karsenti (Eds.), Technology and Changing Mindsets in Education.

Boumova, V. (2008). Traditional vs. modern teaching methods: Advantages and disadvantages of each (Doctoral dissertation, Masarykova univerzita, Filozofická fakulta).

Brush, T. A., \& Saye, J. W. (2002). A summary of research exploring hard and soft scaffolding for teachers and students using a multimedia supported learning environment. The Journal of Interactive Online Learning, 1(2), 1-12.

Ernest, P. (2004). What is the philosophy of mathematics education? [Electronic Version]. Philosophy of Mathematics Education Journal, 18. Retrieved January 1, 2017 from http://www.people.ex.ac.uk/PErnest/pome18/PhoM \%20for_ICME 04.htm.

Eves, H. (1990). An Introduction to the History of Mathematics. New York: Saunders.

Felder, R. M., \& Brent, R. (2005). Understanding student differences. Journal of engineering education, 94(1), 57-72.

Forgasz, H. J. (2002). Teachers and computers for secondary mathematics. Education and Information Technologies, 7(2), 111-125.

Grasha, A. F. (2002). Teaching with style: A practical guide to enhancing learning by understanding teaching and learning styles. Alliance Publication.

Grasha, A. F., \& Yangarber-Hicks, N. (2000). Integrating teaching styles and learning styles with instructional technology. College Teaching, 48(1), 2-10.

Hart, L. (2002). Preservice teachers 'beliefs and practice after participating in an integrated content/methods course. School Science and Mathematics, 102(1), 4-14

Higgins, S., \& Moseley, D. (2001). Teachers' thinking about Information and Communications Technology and Learning: beliefs and outcomes. Teacher Development, 5, 191-210.

Khalid, A., \& Azeem, M. (2012). Constructivist vs traditional: effective instructional approach in teacher education. International Journal of Humanities and Social Science, 2(5), 170-177.

Lakatos, I. (2015). Proofs and refutations: The logic of mathematical discovery. Cambridge University Press.

Lerman, S. (1990). Alternative perspective of the nature of mathematics. British Educational Research Journal, 16, $53-61$.

Loong, E. Y. K. (2003, January). Australian secondary school teachers' use of the Internet for mathematics. In MERGA 26: Proceedings of the 26th Conference of the Mathematics Education Research Group of Australasia, 6-10 July 2003, Geelong, Victoria (pp. 484491). MERGA. 
Philosophy of teaching, teaching style and ICT use: a qualitative study of the perspectives of high school mathematics teachers

F. S. Mensah \& D. D. Agyei

Mensah, F. S. (2017). Ghanaian Mathematics Teachers' use of ICT in Instructional Delivery. Global Journal of Human-Social Science Research.

Mewborn, D. (2002). Examining mathematics teachers' beliefs through multiple lenses. Paper presented at the Annual Meeting of the American Educational Research Association, New Orleans, LA, April 1-5, 2002.

Miles, M. B., \& Huberman, A. M. (1994). An Expanded Source book: qualitative Data Analysis (2nd edn). London: Sage Publications.

Ministry of Education, Science and Sports. (2010). Teaching syllabus for mathematics (Senior High school). Accra: Curriculum Research and Development Division (CRDD).

National Council of Teachers of Mathematics. (2000). Principles and standards for school mathematics. Reston, VA: National Council of Teachers of Mathematics.

Niederhauser, D.S., \& Stoddart, T. (2001). Teachers' instructional perspectives and use of educational software. Teaching and Teacher Education, 17, 15-31.

Proops, I. (2006). Russell's reasons for logicism. Journal of the History of Philosophy, 44(2), 267292.

Putney, L. (2010). Case study. In N. Salkind (Ed.), Encyclopedia of research design (pp. 116-120). Thousand Oaks, CA: SAGE Publications.

Russell, B. (1993). Introduction to mathematical philosophy. Courier Corporation.

Sengodan, V., \& Iksan, Z. H. (2012). Students' learning styles and intrinsic motivation in learning mathematics. Asian Social Science, 8(16), 17.

Serbessa, D. D. (2006). Tension between traditional and modern teaching-learning approaches in Ethiopian primary schools. Journal of International cooperation in education, 9(1), 123 140.

Smeets, E. (2005). Does ICT contribute to powerful learning environments in primary education? Computers and Education, 44, 343-355.

Smeets, E., \& Mooij, T. (2001). Pupil-centred learning, ICT, and teacher behaviour: observations in educational practice. British Journal of Educational Technology, 32, 403-418.

Stein, M. K., Smith, M. S., Henningsen, M. A., \& Silver, E. A. (2016). Implementing standardsbased math instruction: A casebook for professional development. Teachers College Press.

Tall, D. \& Ramos, J. (2004). Reflecting on post-calculus reform. Paper presented at Annual meeting of International Congress on Mathematics Education Teaching Denmark, Coppenhagen. Retrieved December, 2017 from http://www.icmeorganisers.dk/tsg12/papers/tall-mejia-tsg12.pdf]

von Glasersfeld, E. (1995). Radical Constructivism: A Way of Learning (Studies in Mathematics Education Series).

Waite, S. (2004). Tools for the job: a report of two surveys of information and communications technology training and use for literacy in primary schools in the West of England. Journal of Computer Assisted Learning, 20(1), 11-20. 
Wangeleja, M. J. (2010, September). The teaching and learning of competence based mathematics curriculum: Methods and techniques. In A paper presented at the annual seminar of the mathematical association of Tanzania at Solomon Mahlangu Campus of Sokoine University of Agriculture, Morogoro13-18/9.

Weimer, M. (2002). Learner-centered teaching: Five key changes to practice. John Wiley \& Sons.

Wentzel, K. R. (2002). Are effective teachers like good parents? Teaching styles and student adjustment in early adolescence. Child Development, 73, 287-301.

Wims, P., \& Lawler, M. (2007). Investing in ICTs in educational institutions in developing countries: An evaluation of their impact in Kenya. International Journal of Education and Development using Information and Communication Technology, 3(1), 5-11.

Zainal, Z. (2007). Case Study as a research method. Jurnal Kemanusiaan, 9,1-6.

Zilimu, J. A. (2014). Exploring the gender gap in Tanzanian secondary school mathematics classrooms. University of Illinois at Urbana-Champaign. 